Journal of Bangladesh Chemical Society, Vol. 24(2), 115-122, 2011.

DOI: $10.3329 / \mathrm{jbcs} . v 24 \mathrm{i} 2.9700$

\title{
SYNTHESIS AND CHARACTERIZATION OF THE DISUBSTITUTED INDENE DERIVATIVE 3-BENZYL-1-t-BUTYLAMINE(DIMETHYLSILYL)INDENE AND ITS SANDWICH COMPLEX WITH DICHLOROTITANIUM
}

\section{KALIPADA KUNDU*}

Department of Chemistry, Bayreuth University, D-95440 Bayreuth, Germany

\section{Abstract}

The synthesis of the disubstituted indene derivative 3-benzyl-1-tbutylamine(dimethylsilyl)-indene, $3-\mathrm{C}_{6} \mathrm{H}_{5} \mathrm{CH}_{2}-1-\mathrm{SiMe}_{2}\left(\mathrm{NHBu}^{t}\right)-\mathrm{C}_{9} \mathrm{H}_{6}, \quad \mathbf{1}$ and its sandwich complex with dichlorotitanium, $\left[\eta^{5}-\left\{3-\mathrm{C}_{6} \mathrm{H}_{5} \mathrm{CH}_{2}-1-\mathrm{SiMe}_{2}\left(\mathrm{NHBu}^{\mathrm{t}}\right)-\right.\right.$ $\left.\left.\mathrm{C}_{9} \mathrm{H}_{5}\right\}\right]_{2} \mathrm{TiCl}_{2}$ 2, and their characterization using ${ }^{1} \mathrm{H},{ }^{13} \mathrm{C} \&{ }^{29} \mathrm{Si}-\mathrm{NMR}$ and mass spectroscopy have been described.

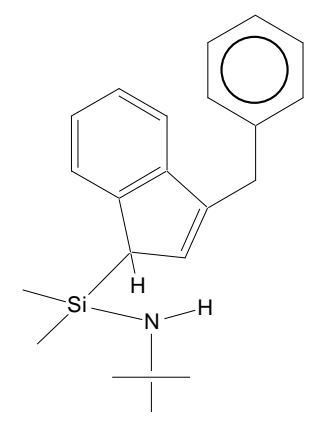

1

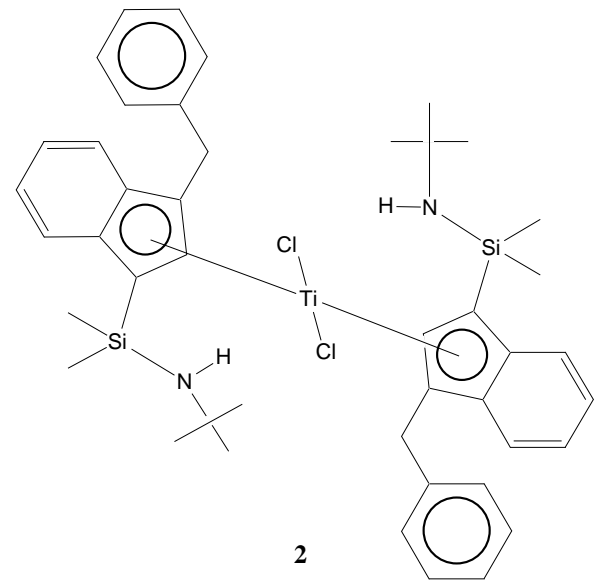

\section{Introduction}

Sandwich and half-sandwich complexes of titanium and zirconium are receiving much interest now-a-days because of their use as catalyst precursors for catalytic polymerization of alkenes. ${ }^{1-5} \mathrm{We}$ also have reported several amido functionalized halfsandwich complexes of the two metals and their successful use as catalyst precursors for homogeneous polymerization of ethylene. ${ }^{6}$ Recently we reported several sandwich complexes of zirconium with disubstituted indenyl ligands. ${ }^{7}$ As an extension of the work the synthesis and characterization of a similar sandwich complex of titanium is now reported.

\section{Experimental} * Present address: Department of Chemistry, Jahangirnagar University, Savar, Dhaka-1342, Bangladesh. E-
mail: kalipadakundu@yahoo.com 
All experimental work was carried out using Schlenk technique under an atmosphere of dried argon. $\mathrm{Et}_{2} \mathrm{O}$, THF and n-pentane were purified by distillation over $\mathrm{LiAlH}_{4}$. Commercial indene, $\mathrm{C}_{9} \mathrm{H}_{8}$, was distilled prior to use and stored at $-30^{\circ} \mathrm{C}$. All other reagent grade chemicals were used without further purification.

The spectrometers JEOL FX 90Q and Bruker ARX 250, AC 300 and DRX 500 were used for recording NMR spectra. The chemical shifts in ${ }^{1} \mathrm{H}-\mathrm{NMR}$ spectra are referred to the residual proton signal of the solvent $\left(\delta=7.24 \mathrm{ppm}\right.$ for $\mathrm{CDCl}_{3}, \delta=7.15 \mathrm{ppm}$ for $\left.\mathrm{C}_{6} \mathrm{D}_{6}\right)$ and in ${ }^{13} \mathrm{C}-\mathrm{NMR}$ spectra to the solvent signal $\left(\delta=77.0 \mathrm{ppm}\right.$ for $\mathrm{CDCl}_{3}, \delta=128.0 \mathrm{ppm}$ for $\left.\mathrm{C}_{6} \mathrm{D}_{6}\right)$. $\mathrm{SiMe}_{4}(\delta=0.0)$ was used as an external standard for ${ }^{29} \mathrm{Si}-\mathrm{NMR}$ spectra. The mass spectra were recorded with a Varian MAT CH7 instrument.

Synthesis of the disubstituted indene derivative 3-benzyl-1-tbutylamine (dimethylsilyl)indene, $3-\mathrm{C}_{6} \mathrm{H}_{5} \mathrm{CH}_{2}-1-\mathrm{SiMe}_{2}\left(\mathrm{NHBu}^{t}\right)-\mathrm{C}_{9} \mathrm{H}_{6} \mathrm{I}$

The preparation of this compound involved the following three steps:

$$
\begin{aligned}
& \mathrm{C}_{9} \mathrm{H}_{8} \stackrel{\text { step } 1}{\longrightarrow} \mathrm{C}_{9} \mathrm{H}_{7}\left(\mathrm{CH}_{2} \mathrm{C}_{6} \mathrm{H}_{5}\right) \stackrel{\text { step } 2}{\longrightarrow} \quad 3-\mathrm{C}_{6} \mathrm{H}_{5} \mathrm{CH}_{2}-1-\mathrm{SiMe}_{2} \mathrm{Cl}_{-} \mathrm{C}_{9} \mathrm{H}_{6} \\
& \text { indene benzylindene 3-benzyl-1-dimethylchlorosilyl-indene } \\
& 3-\mathrm{C}_{6} \mathrm{H}_{5} \mathrm{CH}_{2}-1-\mathrm{SiMe}_{2}\left(\mathrm{NHBu}^{\mathrm{t}}\right)-\mathrm{C}_{9} \mathrm{H}_{6} \longleftarrow \text { step } 3
\end{aligned}
$$

3-benzyl-1-t-butylamine(dimethylsilyl)-indene

Step 1: Preparation of benzylindene, $\mathrm{C}_{9} \mathrm{H}_{7}\left(\mathrm{CH}_{2} \mathrm{C}_{6} \mathrm{H}_{5}\right)$

Indene, $\mathrm{C}_{9} \mathrm{H}_{8},(250 \mathrm{mmol})$ was dissolved in a mixture of $100 \mathrm{ml} \mathrm{Et}_{2} \mathrm{O}$ and $30 \mathrm{ml} \mathrm{THF}$ and the solution was cooled to $-78^{\circ} \mathrm{C}$. n-Butyllithium $(250 \mathrm{mmol})$ was added using a syringe and the reaction mixture was stirred for $6 \mathrm{~h}$ at room temperature. $250 \mathrm{mmol}$ of benzylbromide was next added dropwise at $-78^{\circ} \mathrm{C}$ and the mixture was stirred for another $12 \mathrm{~h}$ at room temperature. It was then hydrolysed with $50 \mathrm{ml}$ water, the organic layer was filtered over $\mathrm{Na}_{2} \mathrm{SO}_{4}$ and the clear filtrate was evaporated to dryness. Distillation of the crude product in vacuo gave $82 \%$ yield of $\mathrm{C}_{9} \mathrm{H}_{7}\left(\mathrm{CH}_{2} \mathrm{C}_{6} \mathrm{H}_{5}\right)$. GC showed it to be about $100 \%$ pure.

Step 2: Preparation of 3-benzyl-1-dimethylchlorosilyl-indene, 3- $\mathrm{C}_{6} \mathrm{H}_{5} \mathrm{CH}_{2}-\mathrm{I}-\mathrm{SiMe}_{2} \mathrm{Cl}$ $\mathrm{C}_{9} \mathrm{H}_{6}$ 
The benzyl substituted indene derivative $(50 \mathrm{mmol})$ was dissolved in $100 \mathrm{ml} \mathrm{Et}_{2} \mathrm{O}$ and cooled to $-78^{\circ} \mathrm{C}$. An equimolar amount $(50 \mathrm{mmol})$ of $\mathrm{n}$-butyllithium was then added slowly and the mixture was stirred for $4 \mathrm{~h}$ at room temperature. The evolution of $\mathrm{n}$-butane was completed in this period. The solution was again cooled to $-78^{\circ} \mathrm{C}$ and added to 3 molar excess of $\mathrm{Me}_{2} \mathrm{SiCl}_{2}$ solution in $80 \mathrm{ml} \mathrm{Et} 2 \mathrm{O}$ at $-78^{\circ} \mathrm{C}$. This was left stirred overnight. To remove the precipitated $\mathrm{LiCl}$, the suspension was filtered over $\mathrm{Na}_{2} \mathrm{SO}_{4}$ and the clear filtrate was evaporated in vacuo to remove solvent and excess $\mathrm{Me}_{2} \mathrm{SiCl}_{2}$. The disubstituted indenylchlorosilane derivative, $3-\mathrm{C}_{6} \mathrm{H}_{5} \mathrm{CH}_{2}-1-\mathrm{SiMe}_{2} \mathrm{Cl}-\mathrm{C}_{9} \mathrm{H}_{6}$, was obtained in about $90 \%$ yield as a light yellow viscous liquid. GC showed it to be about $98 \%$ pure.

Step 3: Preparation of 3-benzyl-1-t-butylamine(dimethylsilyl)-indene, $3-\mathrm{C}_{6} \mathrm{H}_{5} \mathrm{CH}_{2}-1$ $\mathrm{SiMe}_{2}\left(\mathrm{NHBu}^{t}\right)-\mathrm{C}_{9} \mathrm{H}_{6} \mathrm{I}$

To an ether solution of $3-\mathrm{C}_{6} \mathrm{H}_{5} \mathrm{CH}_{2}-1-\mathrm{SiMe}_{2} \mathrm{Cl}_{-} \mathrm{C}_{9} \mathrm{H}_{6}(50 \mathrm{mmol}) 3$ molar excess of tertbutylamine, $\mathrm{H}_{2} \mathrm{NBu}^{\mathrm{t}}$, was added at room temperature and the mixture was left stirred over-night. The hydrogen chloride formed in this step was eliminated by excess amine and precipitated as ammonium hydrochloride. The solvent was removed in vacuo and the residue was treated with about $100 \mathrm{ml}$ pentane. The suspension was filtered over $\mathrm{Na}_{2} \mathrm{SO}_{4} / \mathrm{SiO}_{2}$ and the clear filtrate was evaporated to remove pentane and excess of tertbutylamine. The product 1 was obtained almost quantitatively as a light yellow viscous oil. GC showed it to be about $96 \%$ pure. [Spectral data: ${ }^{1} \mathrm{H}-\mathrm{NMR}: \delta 0.10(\mathrm{~s}, 3 \mathrm{H}), 0.17$ (s, $3 \mathrm{H}), 1.36(\mathrm{~s}, 9 \mathrm{H}), 3.69(\mathrm{~s}, 1 \mathrm{H}), 4.15(\mathrm{~s}, 2 \mathrm{H}), 6.50(\mathrm{~s}, 1 \mathrm{H}), 7.36-7.49(\mathrm{~m}, 10 \mathrm{H}) ;{ }^{13} \mathrm{C}-\mathrm{NMR}$ : $\mathrm{C}_{\mathrm{q}}$ (negative phase) $\delta 49.6,140.1,140.3,144.4,146.2$; $\mathrm{CH}$ (positive phase) $\delta 46.9,119.4$, 123.1, 123.6, 123.8, 124.5, 126.0, 128.3, 128.9, 130.0, 131.1, 132.8; $\mathrm{CH}_{2}$ (negative phase) $\delta$ 34.6; $\mathrm{CH}_{3}$ (positive phase) $\delta-0.7,0.3,33.9 ;{ }^{29} \mathrm{Si}-\mathrm{NMR}: \delta-1.65$. Mass spectrum: $\mathrm{m} / \mathrm{z}$ $335\left[\mathrm{M}^{+}\right], 320\left[\mathrm{M}^{+}-\mathrm{Me}\right], 263\left[\mathrm{M}^{+}-2 \mathrm{Cl}\right], 205\left[\mathrm{M}^{+}-\mathrm{SiMe}_{2} \mathrm{NHBu}^{\mathrm{t}}\right], 130\left[\mathrm{SiMe}_{2} \mathrm{NHBu}^{\mathrm{t}}\right]^{+}$.

Synthesis of the sandwich complex, $\left[\eta^{5}-\left\{3-\mathrm{C}_{6} \mathrm{H}_{5} \mathrm{CH}_{2}-1-\mathrm{SiMe}_{2}\left(\mathrm{NHBu}^{t}\right)-\mathrm{C}_{9} \mathrm{H}_{5}\right\}\right]_{2} \mathrm{TiCl}_{2} 2$

The ligand precursor $3-\mathrm{C}_{6} \mathrm{H}_{5} \mathrm{CH}_{2}-1-\mathrm{SiMe}_{2}\left(\mathrm{NHBu}^{\mathrm{t}}\right)-\mathrm{C}_{9} \mathrm{H}_{6}(10 \mathrm{mmol})$ was dissolved in $\mathrm{Et}_{2} \mathrm{O}(150 \mathrm{ml})$ and the solution was cooled to $-78^{\circ} \mathrm{C}$. A solution of $\mathrm{n}-\mathrm{BuLi}(10 \mathrm{mmol})$ was slowly added to it and the mixture was stirred for $5 \mathrm{~h}$ at room temperature. The lithium salt of the ligand was thus obtained. This was slowly added to a THF solution of $\mathrm{TiCl}_{3}$. THF ( $\left.5 \mathrm{mmol}\right)$ at $-78^{\circ} \mathrm{C}$ and the mixture was stirred for $12 \mathrm{~h}$ at room temperature. For oxidation, the titanium(III) compound thus formed was mixed with $6 \mathrm{mmol}$ (1.66 g) $\mathrm{PbCl}_{2}$ at room temperature and the reaction mixture was stirred for $1 \mathrm{~h}$. When stirring was stopped, the precipitated elemental $\mathrm{Pb}$ and $\mathrm{PbCl}_{2}$ settled at the bottom of the reaction flask. The clear solution from the top was separated using a cannula and the solvent was evaporated in vacuo. The residue was treated with n-pentane, filtered over $\mathrm{Na}_{2} \mathrm{SO}_{4}$ and 
the clear solution was evaporated to dryness in vacuo. The complex 2 was thus obtained as a red solid (yield 62\%).

\section{Results and discussion}

The disubstituted indene derivative $\mathbf{1}$ was used as the ligand precursor for the preparation of the sandwich complex 2. Compound 1 was synthesized from indene, $\mathrm{C}_{9} \mathrm{H}_{8}$, first by substitution with a benzyl group, $\mathrm{CH}_{2} \mathrm{C}_{6} \mathrm{H}_{5}$, next by another substitution with a dimethylchlorosilyl group, $\mathrm{Me}_{2} \mathrm{SiCl}$, and finally by conversion of the chlorosilyl group into the aminosilyl group, $\mathrm{Me}_{2} \mathrm{Si}\left(\mathrm{NHBu}^{\mathrm{t}}\right)$. The reactions involved in these conversion processes are shown in Scheme 1. (Details of the process are given in the experimental section.)

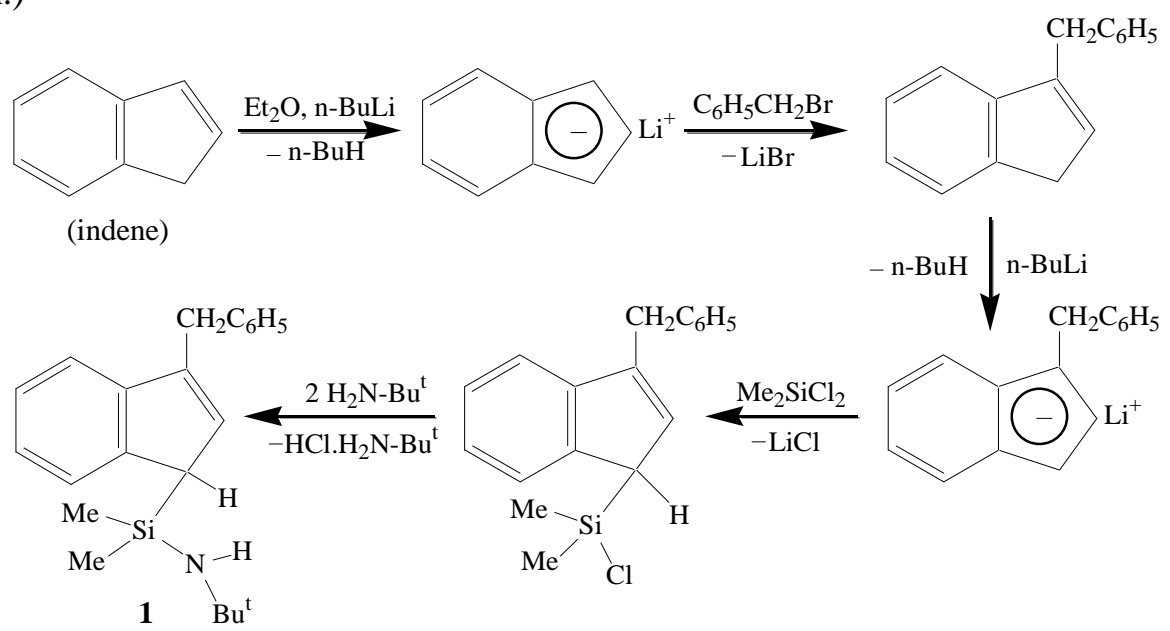

Scheme 1: Synthesis of the disubstituted indene derivative 1 


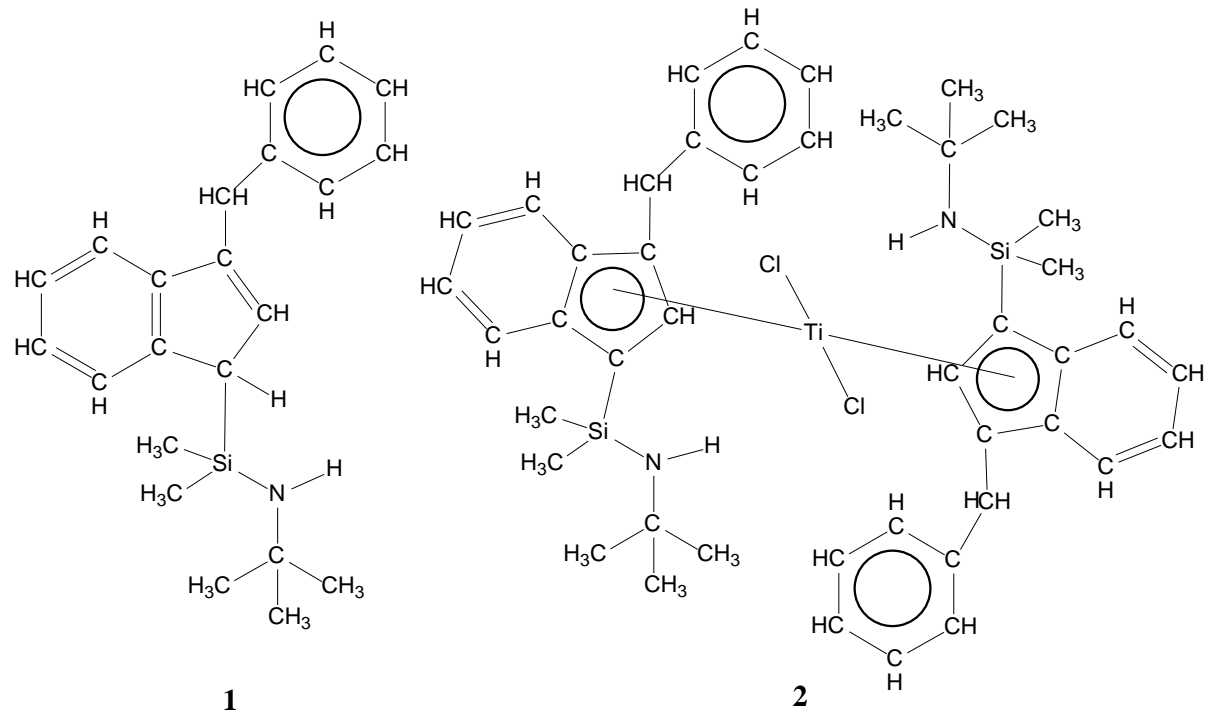

Fig. 1. The detailed structural view of $\mathbf{1}$ and its sandwich complex 2 .

Structures of the ligand precursor $\mathbf{1}$ and its sandwich complex $\mathbf{2}$ with titanium dichloride are elaborately shown in Fig.1. In the ${ }^{1} \mathrm{H}$-NMR spectrum of $\mathbf{1}$ (Fig.2) the aliphatic area showed two singlets of equal intensity at $\delta 0.10$ and 0.17 for the two diastereotopic methyl groups attached to silicon. The three methyl groups of the tert-butyl group, $\mathrm{CMe}_{3}$, are homotopic and showed a singlet for nine protons at $\delta 1.36$. The two methylene $\left(\mathrm{CH}_{2}\right)$ protons of the benzyl group showed a signal at $\delta 4.15$, the silicon- attached $\mathrm{CH}$ proton of the cyclopentadiene ring at $\delta 3.69$ and the NH proton at $\delta 6.50$. Signals for all aromatic protons appeared in the region $\delta 7.36-7.49$.

In the J-modulated ${ }^{13} \mathrm{C}-\mathrm{NMR}$ spectrum of $\mathbf{1}$ (Fig.3) the aromatic region showed four resonance signals with negative phase at $\delta 140.1,140.3,144.4,146.2$ for the four quaternary carbon atoms $\left(\mathrm{C}_{\mathrm{q}}\right)$ present in the cyclopentadiene and phenyl rings and eleven signals with positive phase at $\delta 119.4,123.1,123.6,123.8,124.5,126.0,128.3,128.9$, $130.0,131.1,132.8$ for the $\mathrm{CH}$ carbons present in these rings. The aliphatic area showed one signal with negative phase at $\delta 49.6$ for the quaternary carbon atom present in the tert butyl group $\left(\mathrm{CMe}_{3}\right)$ and another at $\delta 34.6$ for the $\mathrm{CH}_{2}$ carbon of the benzyl group. Two resonance signals with positive phase were observed at $\delta-0.7,0.3$ for the two diastereotopic carbon atoms present in the two methyl groups attached to silicon $\left(\mathrm{SiMe}_{2}\right)$ and another at $\delta 33.9$ for the three homotopic carbon atoms of the methyl groups present in the tert-butyl group $\left(\mathrm{CMe}_{3}\right)$. 


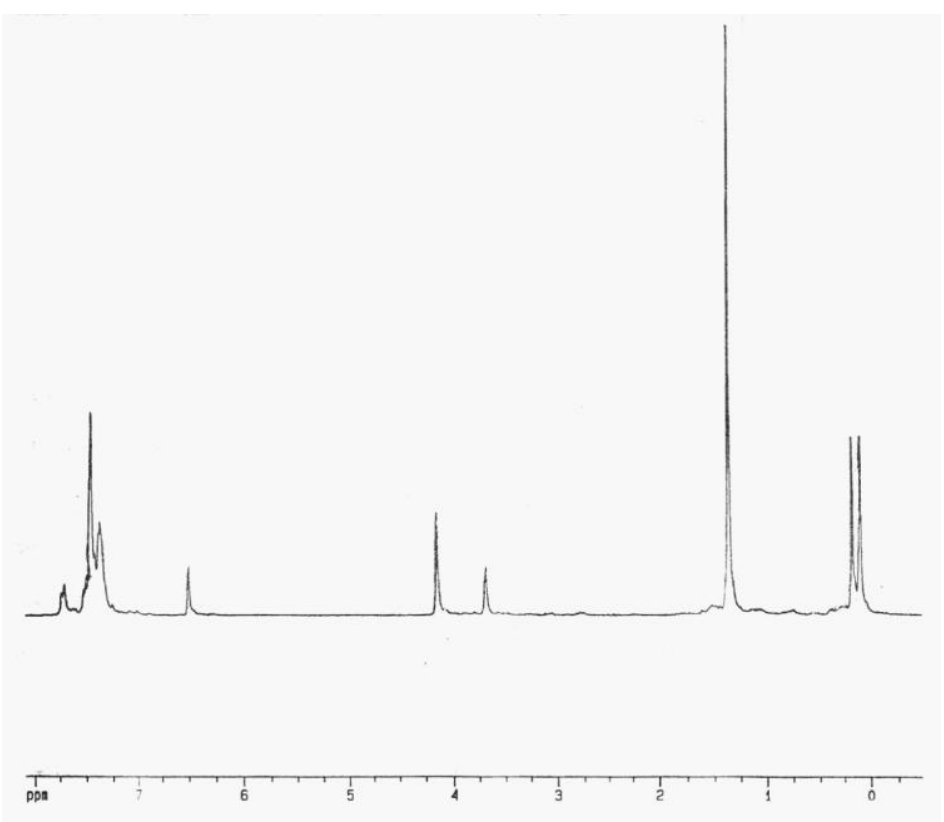

Fig. 2. ${ }^{1} \mathrm{H}-\mathrm{NMR}$ spectrum of the ligand precursor 1.

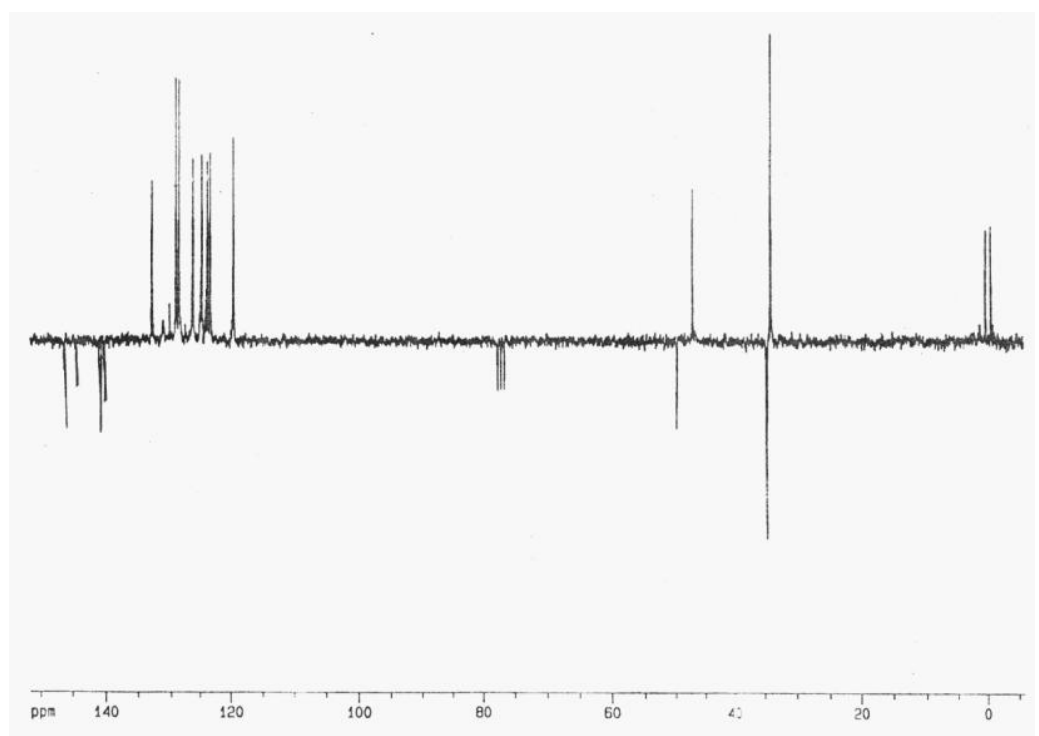

Fig. 3. J-modulated ${ }^{13} \mathrm{C}$-NMR spectrum of the ligand precursor $\mathbf{1}$.

The ${ }^{29} \mathrm{Si}-\mathrm{NMR}$ spectrum showed one sharp signal at $\delta-1.65$ for the silicon atom present in 1. The mass spectrum showed the molecular ion peak at m/z $335\left[\mathrm{M}^{+}\right]$and other mass 
peaks for its different fragments. Thus the structure of $\mathbf{1}$ is satisfactorily established from its various spectroscopic investigations.

The disubstituted indene derivative $\mathbf{1}$ was successfully used as a ligand precursor for the synthesis of the sandwich complex $\mathbf{2}$. For the purpose, $\mathbf{1}$ was first converted to its lithium salt by reaction with butyllithium and this salt was next reacted with $\mathrm{TiCl}_{3}$. THF in THF solution. An unstable titanium(III) compound with 17 valence electrons was obtained which was quickly oxidized using $\mathrm{PbCl}_{2}$ to give the stable sandwich complex 2 with 16 electrons in the valence shell of titanium(IV). It is known from literature that titanium(IV) complexes with 16 valence electrons, e.g. $\left(\eta^{5}-\mathrm{C}_{5} \mathrm{H}_{5}\right)_{2} \mathrm{TiCl}_{2}{ }^{8}$ and $\left(\eta^{5}-\mathrm{C}_{5} \mathrm{H}_{5}\right)_{2} \mathrm{Ti}\left(\eta^{1}-\mathrm{C}_{5} \mathrm{H}_{5}\right)_{2},{ }^{9}$ are sufficiently stable. The reactions involved in the synthesis of complex $\mathbf{2}$ are given below.

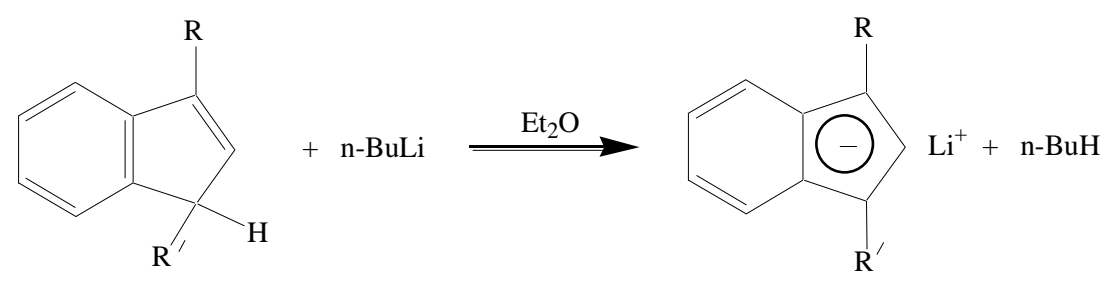

1

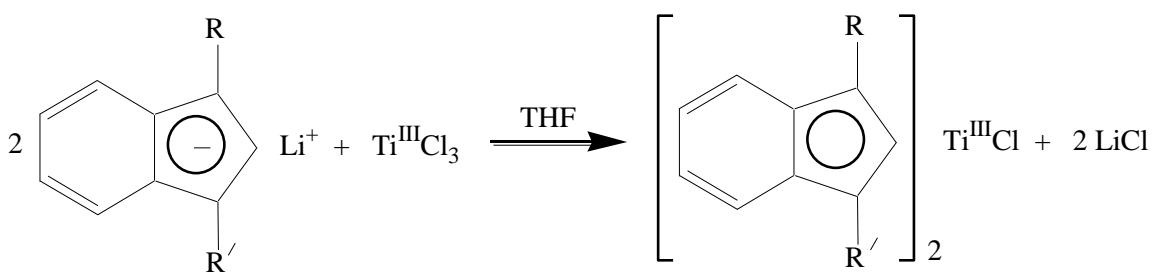

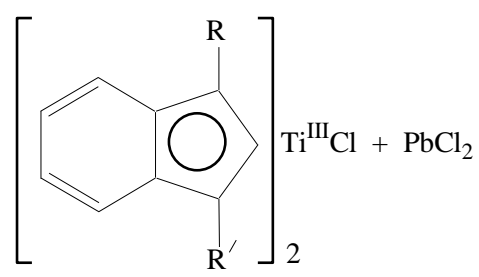<smiles>[R]c1cc(C)ccc1-c1cc(C)ccc1CC</smiles>

$2 \mathrm{PbCl}$ $\mathrm{Pb}+\mathrm{PbCl}_{2}$<smiles>[R]Cc1ccccc1</smiles>

A comparison of the spectral data of complex $2\left[{ }^{1} \mathrm{H}-\mathrm{NMR}: \delta 0.73(\mathrm{~s}, 3 \mathrm{H}, \mathrm{SiMe}), 0.87\right.$ (s, $3 \mathrm{H}, \mathrm{SiMe}), 1.33$ (s, 9H, $\left.\mathrm{CMe}_{3}\right), 4.38\left(\mathrm{~m}, 2 \mathrm{H}, \mathrm{CH}_{2}\right), 6.62(\mathrm{~s}, 1 \mathrm{H}, \mathrm{NH}), 7.13-8.22(\mathrm{~m}$, $10 \mathrm{H}, \mathrm{Ar}-\mathrm{H}$ of indene and phenyl groups). ${ }^{13} \mathrm{C}-\mathrm{NMR}: \delta\left(\mathrm{C}_{\mathrm{q}}\right) 142.3,139.4,135.3,132.4$, 
$124.8,48.6 ; \delta(\mathrm{CH}) 128.4,128.3,128.0,127.6,126.8,126.3,125.4,125.2,124.1,123.7$; $\delta\left(\mathrm{CH}_{2}\right) 34.3, \delta\left(\mathrm{CH}_{3}\right) 3.2,3.6,33.7 .{ }^{29} \mathrm{Si}-\mathrm{NMR}: \delta-11.8$. Mass spectrum: $\left.\mathrm{m} / \mathrm{z} 787\left(\mathrm{M}^{+}\right)\right]$ with those of the ligand precursor $\mathbf{1}$ (given in the experimental section) shows that there are changes in chemical shifts but the nature of the two spectra are very similar. A significant change in the ${ }^{13} \mathrm{C}-\mathrm{NMR}$ spectrum of $\mathbf{2}$ is observed. It shows that a total of six quaternary carbon atoms $\left(\mathrm{C}_{\mathrm{q}}\right)$ is present in $\mathbf{2}$ although five such carbon atoms are there in 1. This is really what is expected because the ligand is coordinated in the $\eta^{5}$ mode in 2 and in doing so $\mathbf{1}$ has to give up the proton of the silicon-attached $\mathrm{CH}$ carbon of the cyclopentadiene ring, thus converting the $\mathrm{CH}$ carbon to a quaternary one and the cyclopentadiene ring to a negatively charged 6e-ligand. The ${ }^{29} \mathrm{Si}$-NMR spectrum showed a single peak for silicon at a different chemical shift from that of $\mathbf{1}\left(\delta_{\mathrm{Si}}:-1.65\right.$ for $\mathbf{1},-11.8$ for 2). The mass spectrum showed the molecular ion peak at $\mathrm{m} / \mathrm{z} 787$ and several other mass peaks for its characteristic decomposition fragments. All these spectral evidences support the proposed structure and formulation of the sandwich complex $\mathbf{2}$.

\section{Acknowledgements}

Grateful acknowledgement is made to the German Academic Exchange Programme (DAAD) for the award of a short-term visiting fellowship for the author to work in the chemical laboratories of the University of Bayreuth, Germany. The author is also grateful to Professor Dr. H. G. Alt of this university for his kind hospitality and helpful discussions.

\section{References}

1. P. N. Nickias, M. H. McAdon and J. T. Patton, PCT Int Appl, 1997, WO 97/15583.

2. R. K. Rosen, P. N. Nickias, D. D. Devore, J. C. Stevens and F. J. Timmers, U S Patent, 1994, 5, 374, 696 .

3. R. E. LaPointe, R. K. Rosen and P. N. Nickias, Eur Pat Appl, 1992, 0495375 A2.

4. J. A. N. Canich and G. F. Licciard, U S Patent, 1991, 5, 057, 475.

5. B. A. Harrington, PCT Int Appl, 1996, WO 96/40806.

6. H. G. Alt, A. Reb and K. Kundu, J Organometal Chem, 2001, 628, 211.

7. K. Kundu and A. Reb, J. Bangladesh Chem Soc, (In press).

8. F. A. Cotton, G. Wilkinson, C. A. Murillo and M. Bochmann, Advanced Inorganic Chemistry, $6^{\text {th }}$ edn., John Wiley \& Sons (Asia) Ptc. Ltd., Singapore, 2003, p. 689.

9. K. Kundu, Elementary Organometallic Chemistry, Bangla Academy, Dhaka, 2007, p. 64. 